\title{
The Push for City Status by Municipal Councils in Uganda: A Dilema for Urban Planning. The Case of Mbarara Municipal Council
}

\author{
John Berch Barugahare \\ Department of Architecture and Physical Planning, School of the Built Environment. \\ Makerere University, Uganda
}

\begin{abstract}
Urbanization is a process through which a proportion of a country's population lives in urban areas increases (World Resource, 1996:96). In Uganda for instance a settlement with 1000 and above people is classified as urban (UBOS, 2005). The urban centres in Uganda are further ranked and gazetted as Cities, Municipalities, Town councils and Town Boards under the Local Government Act Cap. 243. The current ranking gives 1 City; 13 Municipalities; 98 Town Councils, and 207 Town Boards (LGA. Cap 243). The Minister of Local Government using the powers granted under the Local Government Act Cap.243 defines the ranking using the following criteria: population of 500,000 people for a City; 100,000 people for the Municipality; and 25,000 people for a Town Council. That of the Town Board is 1000 persons and above. In addition each of the categories must have a Master / Physical Development Plan; own offices; have available water source; and be able to meet the cost of providing services. Using the same Act, a location identified as District headquarters automatically becomes a Town Council. Each urban centre strives to acquire status of higher administrative level and in this respect the current Municipalities are on the fore front of pushing for City status. Elevation to higher status is supported by the Central Government. Similarly, under 'Vision 2040'Uganda Government seeks to eliminate regional imbalance through establishment of regional cities instead of the current mono-city development dominated by Kampala City (Uganda Vision 2040). Since the Municipalities are spatially small they have to raise the required population threshold of 500,000 people and consequently have been applying the strategy of extending their current administrative boundaries to the surrounding rural areas. The annexed rural areas are brought within the urban planning framework so as to guide the current and future development. Annexation adds to the challenges the current Municipalities face that include : inadequate urban planning operations; lack of planning personnel, planning data, information and drawing tools; lack of transport for movement and surveillance; poor enforcement mechanism; lack of sensitization; budgetary constraints; community perception land tenure system and compensation. These highlighted issues pose a dilemma to urban planning in the old and annexed areas. This is a pertaining situation with the old and annexed areas of Mbarara Municipality that is the subject focus of this paper.
\end{abstract}

DOI: $10.7176 / \mathrm{JEES} / 9-5-07$

Publication date:May $31^{\text {st }} 2019$

\subsection{Introduction.}

1.0 Urban expansion and push beyond the jurisdiction boundaries.

Internal spatial expansion of towns is unavoidable as the urban population continues growing with its requisite activities. This growth pushes beyond the current established jurisdiction boundaries to the surrounding rural areas in form of urban sprawl. This form of sprawl is often referred to as "suburban sprawl" (John Levy, 1991). This tends to follow established communication channels or good scenic landscape. The common forms of sprawl are continuous; leap frog and linear or ribbon development.

Following from the suburban development, Urban Authorities have a tendency of demanding from Central Governments to be allowed to incorporate such areas to their administrative boundaries. The intensions of the Urban Authorities are multi-pronged. The first one is to capture 'financial revenue' in such areas which is in form of taxes and property rates. The other is political where they desire to have bigger administrative constituency and thus higher status in the urban ranking. The third one is that the residents in sprawl areas may request the existing urban centre to incorporate their areas for the latter to legally access the urban services and infrastacture that include piped water, sewerage, electricity, improved roads, health and educational facilities among others

A supplementary reason as the case is in Uganda is that the bigger the Town spatial area and the population threshold it is entitled for more Central Governments funding for classified urban services and infrastructure. Consequently, urban centres in Uganda at different administrative levels strive to move up the ladder. One group that has been pursuing this endeavour are the Municipal Councils who want to be promoted to the rank of City status. 


\subsection{Question of status definition and classification criteria.}

Different countries define the status of their urban centres using different parameters. This in turn is used to define the rank of these centres which are structured in order of importance. Some of the parameters include: administrative definition; population threshold; level of economic, social development; level of physical infrastructure development.

In the case of Uganda, an urban population is defined in terms of a settlement with a minimum population size of 1,000 people (UBOS 2005). Similarly, Uganda Local Government Act 243 Section 32: Third Schedule goes on to categorize urban centres into Municipal Councils / City/ Municipal Division and Town Councils. This same Act empowers the Minister for Local Government to declare an area "urban" if it meets the following criteria: minimum population size of 25,000 for Town Council; 100,000 for Municipal Council; and 500,000 for a City. These urban centres must also meet the criteria of having a Physical Master Development Plan; own operation offices; available water sources; and able to meet the cost of providing services. However, if an area is identified as a District headquarters it automatically becomes a Town Council. Brought within the administrative urban ranking structure is the "Town Board." The urban centres ranking is highlighted in Figure 1.

Figure 1: Hierarchy of Urban Centres.

Source: Ministry of Local Government, 2016

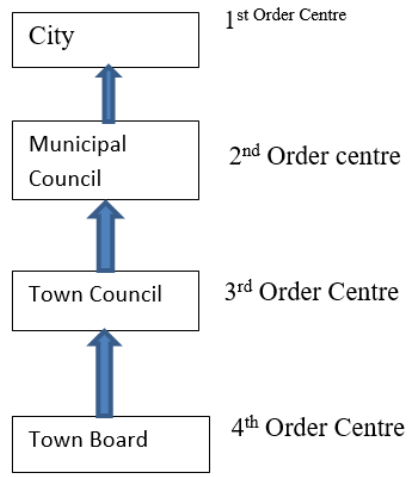

Given the hierarchical structure as indicated in Figure 1, there is only 1 City, 13 Municipal Councils, 98 Town Councils and 207 Town Boards (UBOS, 2002).

\subsubsection{Best Practice of Municipal Boundary extension and the case in Uganda.}

There is very limited literature on boundary revision in Uganda hence an examination of this subject is supplemented by drawn experiences from other countries such as South Africa and Canada. This is in form of best practice on Municipal Boundary extension where the author shows the variations with Uganda and pointing out gaps with Uganda's experience.

In South Africa for instance the governance system must be in line with the Country's Constitution requirements and national legislation. There is a Municipal Demarcation Act under which an Independent Municipal Board is established. This determines the category of towns and outer boundaries and the wards (Sutcliffe 2012). The same Board provides advice to Government and works with Government departments to align Municipal Boundaries and service government delivery regions. Thus Sections 21 and 25 of the Act spell out how the Board is mandated to carry out the Municipal boundaries demarcation; receive complaints of grieved parties and act; the criteria used for demarcation; the procedures and processes of boundary demarcation. The Act spells out the need for public representations and need for meetings and formal investigations (ibid, 2012). The Board ensures that the process is all inclusive of the stakeholders.

A second case is that of the Municipal boundary revision in the Province of British Columbia in Canada. The Local Government Department of the Ministry of Community Services is responsible for the review and implementation of changes to Municipal boundary extensions. The Ministry applies a policy and processes for Municipal boundaries extensions and criteria for their approval (Ministry of Community Services, British Columbia. 2005).

The Ministry's approach is guided by four policy principles that include: municipal initiative in boundary extension; provincial approval through an Order of Council; Citizen's consent in proposed extension areas; inter-jurisdictional collaboration where the neighbouring Authorities are consulted; definition of nature of local government and the processes for creating and criteria for changing the boundaries of individual local government. The legislative provisions governing Municipal boundary extension are contained in Section 20 of the Local Government Act (ibid, 2005).

1.1.2 The process and procedure of Municipal boundary extension in Uganda.

There are differences in procedures, processes and criteria applied in boundary revisions and extensions between what is applied in Uganda and the two foregoing identified cases. The fundamental differences are that in the 
former cases there is public consultation of the affected stakeholders in the areas marked for extension. This would entail approval or rejection of the proposal for extension. In the case of Uganda the boundary extension proposals are dictatorial where the affected stake holders are informed the following day that they are now part of town. Similarly, unlike in Canada and South Africa, where there are legally constituted bodies that carry out studies, findings and recommendations to the Ministries and Local Authorities for approvals, in Uganda the Ministry of Local Government takes the centre stage using the provisions of the Local Government Act. Cap 243. (LGA. Cap 243). Similarly in the case of Uganda the areas that are annexed which are rural areas are a result of negotiations between the Municipal and District Councils. Similarly, there is no consultation with the affected communities in the annexed areas.

While the Municipality may pursue boundary extension as a strategy to raise the required threshold population for City status, there are established processes this has to go through. The Local Government Act Cap 243. (Sub-section 4) indicates that "The Minister is the 'steward' of the Municipal boundary extension process following the established guidelines for process". Thus the stages under which the LGA Cap. 243 approves Municipal boundary extension (LGA 243,) include: the Municipal consideration of the boundary extension; Submission of endorsed boundary proposal to the Ministry of Local Government; Ministry of Local Government consideration; statutory advertisement, and then subsequent implementation if there are no objections.

\subsection{Boundary extensions and City status establishment}

As the numbers of urban centres increase this has to correspondingly be matched with the urban services and infrastructure they provide. Similarly, the consequent growth of population and urban activities has to be accommodated within the town boundaries that necessitate revision.

This also results into the ranking of the Town status to further propel development through government support financially. For instance the strategy of attaining City status would enable those ones aspiring for this rank to receive increased Local Government funding for their development programs. A case in point is that in 2008/09 Financial Year where Urban Local Government funding constituted 3.4 \% (Shillings 40billion) of the shillings 1.2 trillion, sent by Central Government to all Local Governments (National Urban Policy Development Support-Urban Situational Analysis- MOLG 2010)

Similarly, in line with supporting a balanced Regional growth the Government adopted a Policy of establishing 'Regional Cities' in its 'Vision 2040' instead of the current mono-city strategy This is expected to reduce development pressures on Kampala City and hence address regional economic disparities (The Uganda Vision 2040, $2^{\text {nd }}$ National Development Plan 2015/2016-2019/20) and regionalization of key services. The identified Municipalities to be elevated to City status include: Fort-Portal; Mbarara; Arua; Gulu; Jinja and Hoima. Of these identified Municipalities slated for elevation to City status it is Mbarara Municipal Council that has been pushing vigorously. According to Central Government plan this Municipality is slated to become a City by July 2017.

\subsection{Municipal Council pursuance of City Administrative status}

2.1 Genesis and growth of the Town: Located in south western Uganda, Mbarara was identified as administrative centre of Western Region around 1900 (UN-Habitat, 2010). Its name is derived from the local grass called "emburara" which covered the area. Real growth of the centre began with arrival of Asians in 1950s. Increased development activities were more marked in 1957 and that was the time this Town was elevated to Town Council status. The Town was multi-cultural but with clear class residential divisions of Asians in Kakooba; the Europeans in Booma and Africans around Kamukuzi the then seat of the then King of Ankole Kingdom (ibid, 2010).

However the urban morphology was based on racial lines with Europeans in better planned and well served areas with physical infrastructure as roads, water, sewerage, recreational open spaces. Then there were those areas which were fairly served and these were settled by Asians. The least served were those where the Africans lived. This system based on racial spatial segregation has since independence in 1962 been dismantled but substituted with income segregation structure instead. The high incomes live in well served areas followed by medium income groups in fairly served areas. The low income bracket gets least of the urban services.

The growth of the town continued in the sectors of trade and commerce; education; transportation and in 1974 it was farther elevated to Municipal Council level. Corollary, the urban population has been rising due to both natural growth and rural-urban migration. The 2002 Town recorded population is 69,400 (UBOS, 2002), which had also been projected to 82,000 people (ibid, 2002) and a mid-year population of 83,700 people. However, the latest National Population and Housing Census in 2014 gives figure of 195,013 (UBOS, 2014).

This latest population figure of 195,000 people still falls short of the set 500,000 population threshold for a City status. This is therefore surpassed by political decision to earmark the Municipality for City Status. At the growth rate of $5.5 \%$ the Municipality will achieve the 500,000 population threshold within 10 years 


\subsection{Spatial expansion: Annexation of surrounding sub-counties.}

As an attempt to raise the required minimum population for the city there was spatial expansion of the Municipality that emanated in annexation of the three surrounding administrative sub-counties as indicated in Map 1.

Map 1: The Old Municipality Divisions and the Annexed Sub-counties: Proposed City Boundaries

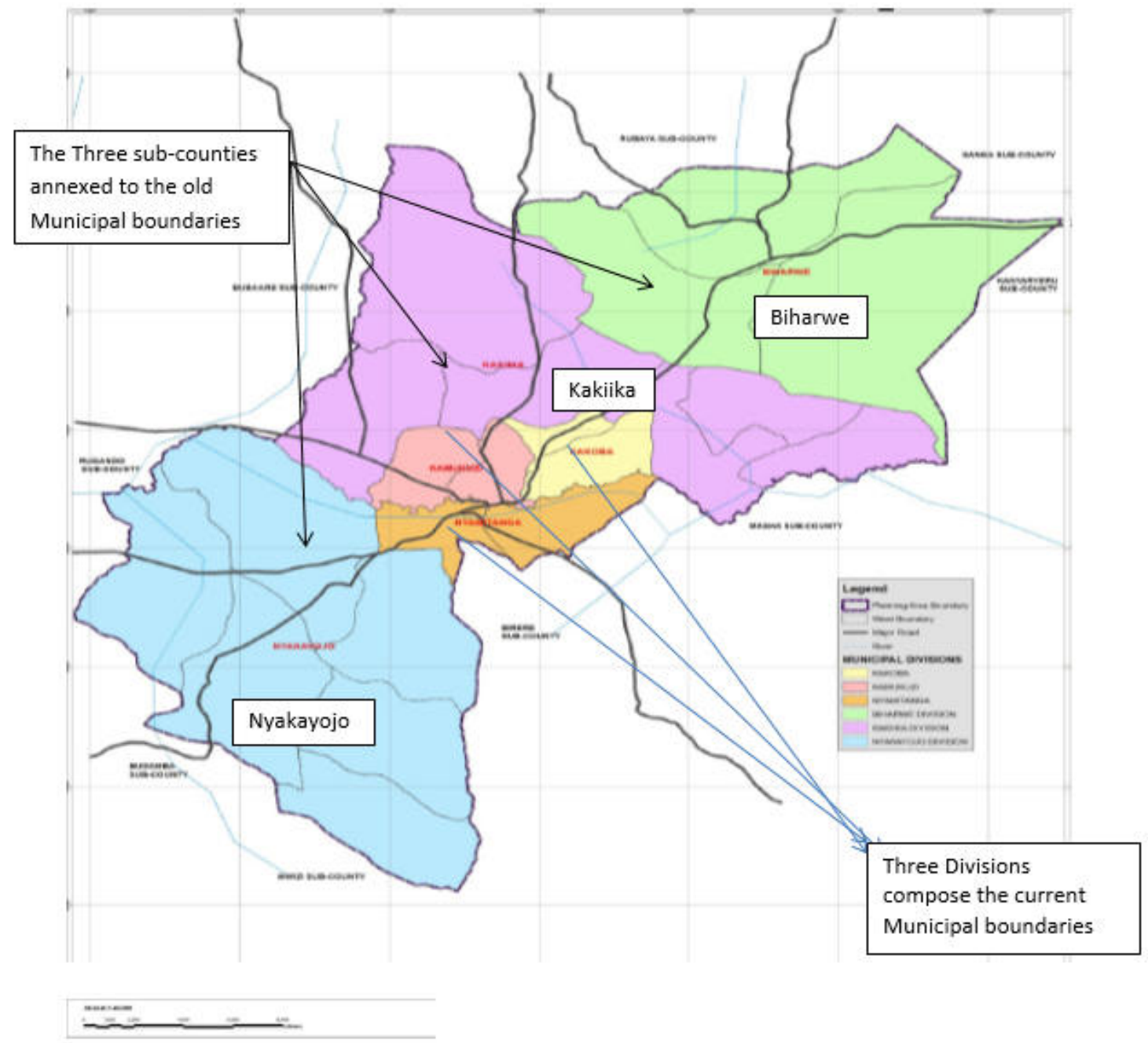

Source: Mbarara Municipal Council, 2016.

These are sub-counties are Local Governments at 'local Council III Level'. The population of these is part of the 195,000 Municipality populations. The sub-counties annexed include Nyakayojo; Kakiika and Biharwe (Map 1) which have now been turned into Municipality Divisions. This annexation of the sub-counties has spatially enlarged the Municipality area by 10 times from 51.7 sq. km to an area of $578 \mathrm{sq} \mathrm{km}$. (Map 1). The subcounties turned into Divisions and their requisite population are indicated in Table 1 and the overall Divisions forming the expanded Municipality are indicated in Table 2.

Table 1: Spatial areas in Km. sq. of the annexed sub-counties.

\begin{tabular}{|l|l|l|l|}
\hline & Su-county & Area Km sq. & Population (2014 Census) \\
\hline 1. & Biharwe & $146 \quad 1,941$ \\
\hline 2. & Kakiika & 180 & 21,973 \\
\hline 3. & Nyakayojo & 252 & 38,252 \\
\hline
\end{tabular}

Source: Uganda Bureau of Statistics, 2014. 
Table 2: The current Municipality Divisions and the Population.

\begin{tabular}{|l|l|l|}
\hline No & Divisions & Population (2014) \\
\hline 1. & Nyamitanga & 23,314 \\
\hline 2. & Kakooba & 55,519 \\
\hline 3. & Kamukuzi & 34,014 \\
\hline 4. & Nyakayojo & 38252 \\
\hline 5. & Kakiika & 21,973 \\
\hline 6. & Biharwe & 21,941 \\
\hline Total & Municipality & $\mathbf{1 9 5 , 0 1 8}$ \\
\hline
\end{tabular}

Source: Uganda Bureau of Statistics, 2014

2.3 Current urban Development trend: The on-going rapid urban development in various sectors supported by the Town's geographical location with wide business hinterland; centre of innovation and transportation connectivity has catalysed the demands from the local policy makers to have the Municipality elevated to City status. Significant growth is taking place in Industry that include processed milk; Coca Cola and Beer brewing (Nile Beer Brand) factories; fruit and juice; metal fabrication; banking ( 8 banks); microfinance; transport. The service industry is also on the rise that includes radio stations and a Television Station. There are several furniture workshops; Banks; Hotels; Textile and knitting enterprises; and Educational institutions at various levels which also include two universities.

\subsection{Dilemma to Urban Planning}

3.1 The urban Planning episode overtime: The first urban planning scheme for Mbarara Town was in 1955 the time that the old established Town Councils had their Town Plans prepared throughout the country. That time both the population and Town spatial area were small. Similarly it was easy to implement and control development. The planning processes and procedures were modelled along the 'master plan' philosophy of planning from a clean slate and 'the plan must rule' which was the paradigm after World Two (Taylor, 1998). Most important is that this form of town planning was meant to serve the colonial administrators' interests and left the indigenous areas outside the planning framework. At the same time the indigenous residing in Town was restricted and where they did were confined in specified areas (source)

3.1.1 The second planning scheme that followed was that prepared in 1984 known as 'Mbarara Development Plan'. This Plan was prepared under the guidance of the Reconstruction and Redevelopment Corporation (R.D.C) established by Act of Parliament in 1981. The Corporation had been set up to speedily reconstruct the destroyed towns of Arua, Masaka and Mbarara that had been significantly destroyed during the 1979 war. Urban planning was identified as one of those key strategic areas to propel orderly spatial reconstruction activities, and consequently the 1984 Mbarara Development Plan was prepared under this premise.

This town Development Plan could not be effectively implemented due to political, financial and economic instability prevailing then. There was fluid commitment to implement the plans provisions on the ground by the population, Central Government and the Urban Local Government of the day.

This plan had to wait for revision until 1997 when a new 'Mbarara Structure Plan 2008-2018' was produced under the 'Local Government Development Programme' (LGDP II) (MOLG 2008). The plan had implementation challenges in many areas and consequently the Municipality has had to initiate a project to review it. This current planning scheme being prepared has included the three sub-counties that have been annexed which now Administrative Divisions of the Municipality. The annexed new areas have added to the already cumulative challenges of urban planning. This adds to the cumulative dilemma already faced by the Municipality.

\subsubsection{The issues arising.}

i. Large planning area. The Municipality is now expanded ten times the size of the original Town area. Although there is a 'Structure Plan 2008-2018' that covers the old town administrative area which is broad in nature, the lower level plans as 'detailed plans; areas action plans' cover only $30 \%$ of the of the old Municipality (Mbarara Municipal Council, Physical Planner's Office, 2015). The annexed areas have not had any formal physical planning. Thus the Municipality has taken on extended areas that remain without planning attention and will probably remain so in the short run, since it still has not covered the deficit of $60 \%$ in the old Municipality area...

ii.Constraining land question and the District Land Board. The Constitution of the Republic of Uganda 1995, under Article 237, grants land ownership to the citizen of Uganda (Republic of Uganda Constitution, 1995). To this effect urban planning which is a key instrument of land management is to be extended to these annexed areas. Consequently, statutory practices will be applied using spatial urban plans to promote physical, social, economic order and integrated development. This will affect peoples' interests not only on right of use of 
land but also where land is required for public services and infrastructure under the clause of 'public' good.

At the same time Article 26 (1) of the Constitution guarantees a right to own property individually or in association with others. Thus in Section (2) it is stated that no person shall be compulsorily deprived of property. Where there is compulsory acquisition for public good as schools, health, roads and other public infrastructure, prompt payment of fair and adequate compensation prior to taking of possession or acquisition of the property.

Article 26 has good intentions to protect the right to individual property; it has its constrictions on urban planning processes and implementation. This is so with delays in land acquisition and high price for compensation. This is a feature that is to be equally faced in the areas of annexation that will constrict implementation of planning.

Similarly, under Article 240 (1) of the 1995 Constitution created District Land Boards. The functions are spelt out in Article 241 and The Land Act Cap 227 Section 59 (1) that include: holding and allocating land (include urban areas) that is not owned by any person or institution; facilitate registration and transfer of interests; deal with other matters connected with land in accordance with laws prescribed by Parliament and cause surveys, plans, maps, drawing and estimates to be made by or through its officers or agents. The District land Board has had frequent clashes with the old Municipality where it allocates land not in conformity with the Municipal Land use plans. Similarly, there are renewal of leases of which the affected uses no longer conform to the initial plans thus not adhering to the changed planning and development requirements and standards. This situation will greatly constrict urban planning in these annexed areas through initial community resistance.

Thus land planned for public amenities and infrastructure is likely to be inhibited in acquisition because of heavy compensation and unwillingness by the owners to be reluctant to surrender their lands. This will constrain plans implementation, thus many areas will remain unplanned.

iii. Cultural inhibitions to urban planning. The majority of inhabitants in the annexed areas still maintain their rural practices which are different from the urban way of lifestyle. Consequently there is a likely hood of a clash between urban planning which reflects the modern and western values norms as opposed to the locals perceptions of handling development. The urban planning that has to be introduced in these areas through laws, regulation and controlling development is likely to be confronted with some resistance and hence noncompliance. The urban planning practices is expected to affect the range and type of individual land use activities which the individuals will see as interfering with the righto use of land. This would affect the type of plans put on board but also their implementation.

vi. The community participation challenge. Community participation in the planning processes in the Towns of Uganda is generally low as by the Report of the 'Uganda Urban Authorities Association, 2011' (UUAA, 2011).Decision making processes were found to be dominated by technocrats, and policy makers who are the politicians. More important also is that the communities had apathy on participation and took it that it was the responsibility of the Municipality to take decisions. This was revealed by an investigative Report that covered 20 Urban Authorities throughout Uganda. The Towns included Municipal Councils, Town Councils and Town Boards. Mbarara Municipal Council was among the 20 Towns.

Low participation enthusiasm is not exclusive of the Town population but part of the general behaviour even in the surrounding areas. This is likely to be confronted in these annexed areas a factor that would not promote the desired urban planning processes and implementation. Low participation is also identified as a result of lack of community sensitization and involvement in planning process.

It should also be noted that a key constraint to participation as Jjuko (2013) points out is illiteracy. People have not attached the value of participating in decisions that affect them. This is likely to be predominant in these rural areas that have now been brought within the Municipality and which is likely to hamper urban planning processes and implementation

v. Inadequate planning resources: manpower and urban planning tools. The Municipality has an establishment structure that provides for only one Physical Planner. This Municipal Urban Planner is already overstretched and unable to provide the required urban planning and land management needs. Extension of the Municipal boundaries means more urban planning load of which the current Municipal Physical Planner is incapacitated. This similarly means that urban planning which is exigent in guiding urban development will continue to remain peripheral. This is also likely to lead to proliferation of slums and informal settlements in these areas. This situation is made worse by not having any support staff in the planning office and hence has to use personnel from other units / Departments.

In addition, the urban planning office is incapacitated by serious lack of planning tools and equipments as maps; drawing materials; drawing computer software; drawing tables and GPS machines and transport facilities. With extended Municipal boundaries this entails more of these logistical materials but of which may not be availed because of constrained finances. This will result in not only being unable to execute planning but also enforce the Development control.

A supplementary issue that is likely to constrain urban planning in the annexed areas is inadequate planning data and information. Already the current Municipality area does not have up to date satellite images, 
topographic and cadastre maps. The situation is to get worse in the annexed areas because they do not have such but also tailoring these maps to the scales of 1:2.500; 1:5000; which are commonly used in planning at the local level.

vi. Likely Political interference with planning in the new areas and. Political interference is identified as one of constraints faced in promotion of Urban Planning and requisite urban development. The areas' local politicians always want to safeguard their interests by protecting the locals land use and land management intentions. The locals are voters the politicians cannot afford to ignore and hence have to defend them. This is not that the planning intentions are bad, but they constrict some activities that are contrary to the objectives of urban planning. To some individuals planning process is not regarded as benefiting the community as a whole but a few and thus tend to get resisted. This situation is likely to pertain in the new Municipality boundary areas thus inhibiting urban planning

vii. Inadequate funding. Mbarara Municipality is faced with inadequate funds to implement her various sector programs. One of the sectors' programs inhibited is 'urban planning'. Information obtained from Mbarara Municipality (2015) indicate that only 35 million shillings was allocated to Physical Planning during Financial Year 2013/2014. While the Central Government sent in grants these were based on the population established every 10 years by Uganda Bureau of Standards (UBOS). The ten year period is long and a lot of changes take place in between. At the same time the Municipality has not widened its revenue base. Given this scenario Urban planning has to compete with other sectors but not on a highly prioritized consideration level. This tantamounts to getting least allocation for its operations. Table 3 highlights this picture of the Council budget and allocation made to Urban planning.

Table 3: Mbarara Municipality Budget and allocation to Physical Planning F/Y 2014/2014

\begin{tabular}{|l|l|l|}
\hline Budget in Billion Shillings & Local Revenue as \% of Budget & $\begin{array}{l}\text { Allocation to Physical Planning programs } \\
2013 / 2014\end{array}$ \\
\hline $8,000,000,000$ & 25 & $35,000,000$ \\
\hline
\end{tabular}

Source: Mbarara Municipal Council, 2014.

With stretched administrative area it means more money to spend but correspondingly less on the stretched urban planning range of operations. Thus implementation of urban planning programs is likely to be constrained.

v.Outdated data, Information and logistics constraint. Currently the Municipality faces a situation where it has got out-dated data and information for urban planning. The planning statistics are old; the maps used for planning at the required planning scale are those of 1964 and a few generated during the 1984 and 2007 period during the preparation of the Town's Development Plan and the Structure Plan respectively. There are no recent aerial photographs of the Town. While Satellite images can be obtained they cab secured at a high cost which often the Municipality is not able to afford.

Similarly, the Municipality's urban planning is constrained by inadequate logistical equipments. The Urban Planning section has no vehicle for office and field operation and the office accommodation is shared with other units. There are no simple drawing tools as pens, tracing paper, drawing scales, templates, French curves, stencils and plans printing machines. There is only one computer but has no design software

With the extended Municipality boundaries means more demand for data, information infrastructure which is up to date and that which can inform decisions for urban planning and policy decisions. Similarly, there great need for movement over this stretched area for regular planning activities and guidance but also surveillances to enforcement the planned development. Hence, urban Planning is likely to remain ineffective in the annexed areas unless the highlighted setbacks are exigently handled.

vi. Dilemma within a Dilemma. The current urban planning system itself is inappropriate as is re-active, nonparticipatory and little emphasis on integration and co-ordination. The system is also piecemeal and not focussing on planning issues as a whole

\section{Conclusion.}

From the analysis given the boundary extension procedure is the same for all urban centres regardless of the rank. What is also brought out is that there is no community consultation in those areas earmarked for annexation to give their views. No technical advice and others.

\section{References}

1. Ministry of Community Services, Province of British Columbia, Canada, 2005. Municipal Boundary Extension Criteria, Pp. 1-25. Victoria, BC.

2. Ministry of Community and Rural Development, Province of British Columbia, Canada. 2010. Municipal Boundary Extension Process Guide. Pp. 1- 4. Victoria, BC.

3. Levy, J. 1991. Contemporary Urban Planning, Second Edition. Pp, Prentice Hall, Englewood Cliff NY.

4. Government of The Republic of Uganda, 1995. The Local Government Act. Cap 243. PART II-LOCAL GOVERNMENTS, Article 3-9, 578-581 
5. Ministry of Local Government, Uganda, 2008. Mbarara Municipal Council Structure Plan 2008-2018, Pp. 1418.

6. Ministry of Local Government, Uganda, with support of UNDP 2010. Urban Situational Analysis in Uganda, Report. Pp. 41-45. Kampala, Uganda.

7. Ministry of Community Services, British Columbia, Canada, 2002. Municipal Boundary Extensions Criteria. Pp.1-25. (Revised June 2005)

Source: www.rl osmaps.bc.com/Min-by lows/new and events. Newsletter/ Area D-Municipal-BoundaryExtension-Criteria-pdf. Accessed: 02/09/2016

8. Ministry of Community and Rural Development, British Columbia, 2016. Municipal Boundary Extension Process Guide, March 2016, Pp.1-18.

Source:www.csd.gov.bc.co/igd/gov. structure/library/ Municipal-Boundary extension-process-Guide.pdf. Accessed: 02/09/2016.

9. Reconstruction and Redevelopment Corporation (RDC), 1984. Mbarara Development Plan 1984.Pp...... Mbarara, Uganda.

10. Sutcliff, M.2016. The South African Municipal Demarcation Process. Http:// halshs-archivesouvertes.fr/halshs-00766930.Pp.1-11. Accessed: 09/10/2016

11. Taylor, N. 1998. Urban Planning Theory since 1945. 'Town Plans as detailed blue prints or Master Plan (Pp. 14-17; 20-27). Sage Publication, Thousand Oaks CA.

12. Tumwine, W. 2013. Mbarara Municipality Profile and Need for expansion. Pp. 1-5. Mbarara Municipal Council Headquarters, Mbarara.

13. Uganda Bureau of Statistics, 2014. Uganda Population and Housing Census. Pp. 61 Uganda Government Publication, Kampala.

15. UN-Habitat, 2012. Mbarara Municipality Profile.Pp. 11-52. United Nations Centre for Human Settlement, Nairobi, Kenya

16. Urban Authorities Association of Uganda (UAAU), 2011. Report on Study on The Implementation of Physical Plans in Local Governments, Uganda.Pp..31-35. Kampala, Uganda.

17. The Government of Uganda. 2015. The Big Dream. Uganda's Future Vision 2040, 'Urban Development'. Pp.13-14. Kampala, Uganda. 